\title{
Shopping as a selling strategy for tourism: combination of marketing mix tools ${ }^{1}$
}

\author{
PhD. Gloria Jiménez-Marín \\ University of Seville. Spain. \\ gloria_jimenez@us.es \\ ORCID: https://orcid.org/0000-0003-0252-3975
}

DOI: http://dx.doi.org/10.12795/IROCAMM.2018.i1.05

\begin{abstract}
The use of time for entertainment has increased participation both at home and outside and, in our days, we look at the proliferation of a wide range of activities that are included in the leisure economy: tourism, catering, shopping, sports, entertainment... In this sense, a lot of studies agree that the activities related to leisure time of individuals with strong potential for growth as amusement parks, restaurants, tour operators... and, above all, new retail formats that are configured as great business opportunities.

Consequently, the main objective of this text is to relate some of the main activities that are encompassed in the new economy of leisure. And as a specific example to analyze the complementarity between trade and tourism in a particular case: Shopping in Seville.

Firstly, there exists a theoretical review of the phenomenon of leisure within the needs of
\end{abstract}

individuals and further expenditure is oriented towards this set of activities. Then a classification of the activities offered for the entertainment of individuals paying particular attention to the main Spanish companies involved in some of these sectors and, secondly, the role of shopping as one of the leading suppliers of trade and leisure.

Finally, exercise has articulated a dual approach to complementarity between the commercial and tourist activities, first of all, we performed a quantification of non resident consumption by commercial areas, and afterwards, it has developed a classification of regions in terms of its commercial and tourism potential through a cluster analysis.

Keywords: Citymarketing, Citybranding, Shopping, Seville, Tourism.

\footnotetext{
${ }^{1}$ Paper within the R + D + I proyect: Online Communication tourist destinations (CODETUR), funded by Ministerio de Ciencia e Innovación (Ministry of Science and Innovation) of Gobierno de España (Government of Spain).
} 


\section{Introduction}

Leisure, increasingly, is also consumption, so the commercial sector strategies and approaches for the future, inevitably into the field of leisure being considered as a factor of high value to the traditional business. One of the main activities carried out in the leisure tourism are travels, which are linked together not only with tourism services but also has a strong economic impact on the commercial distribution sector given the importance in the international Spanish tourism market.

So, the use of time for entertainment has a growing involvement at home and outside it and, in our days, we look at the proliferation of a wide range of activities that fall into the leisure economy: tourism, restaurants, shopping, sports, entertainment... Thus, more and more abundant studies agree that the activities related to leisure time individuals have a high growth potential, that is, leisure parks, fast food establishments, tour operators and travel agencies, hotel chains, publishing or new retail formats appear as major business opportunities in this new century. This paper is structured in three sections besides this introduction, a brief endnotes and references.

\section{Objectives}

The main objective of this study is to analyze the relationship between variables 'purchases' and 'visits' in tourist destinations. Thus, we question how empowering procurement routes influence urban tourism while analyzing the strategies undertaken by the city of Seville (central and metropolitan area) to get boost sales of shops and restaurants in the Andalusian capital and, thus, increase tourism.

The main objective is accompanied by other equally relevant. The introduction has placed the state of affairs in the communication and promotion of tourist destinations through a long-term strategy with tactics that come together in the tertiary sector: trade and services.

Furthermore, research should serve to deepen the specific concepts and increasingly developed and are citybranding shopping or tourism. Consequently, the main objective of this article is to relate some of the main activities that are covered by the 
new economics of leisure. Namely, is to analyze the complementarity between trade and tourism.

Finally, the joint analysis should lead to operational conclusions to open new lines of research.

\section{Theorical framework}

\subsection{From citymarketing to citybranding}

The concept of marketing applied to cities is a relatively new concept. But not for this reason, the tourist companies forget this technique; in recent years the care is bigger even in managing the promotion / sale of the cities. It is true that tourism-related businesses have traditionally gone to specific strategic approaches and tactics to attract the target audience; the news is linking the possible strategies to attract tourists not only to the tourist agents, but the concept of the city as fully marketable product in terms of image and salable economically.

A strategic marketing plan is a plan called 'citymarketing', that is, a must "para la concepción actual de las ciudades como centros de atracción socio-económicos y culturales"1 (López, 2007: 57). We can say that the concept of 'citymarketing' is a research process that highlights aspects that are real barriers to the development of the city while trying to understand the city as an object, as a commodity. In the words of Lopez (2007: 63):

"El citymarketing aprovecha así las últimas aplicaciones de la mercadotecnia turística, del marketing cultural y del patrimonio, al tiempo que elabora sus presupuestos y propuestas de acción con una visión a largo plazo" ${ }^{\prime 2}$.

In line with the concept of marketing applied to destinations we find DMO (Destination Marketing Organization) that, for Gartrell (1994) are, simply, organizations established to promote specific destinations among potential travellers. A similar concept is Convention and Visitor Bureau, characterized as a small or medium non-profit organization, which makes a wide range of information and communication activities to facilitate the development and promotion of tourism in certain geographic areas (Yuan, Gretzel y Fesenmaier, 2003).

\footnotetext{
1 "For the current conception of cities as centers of attraction socio-economic and cultural".

2 "The citymarketing take advantage the latest applications of tourism marketing, the marketing culture and heritage, while it prepares its budgets and proposals for action with a long-term vision".
} 
For Forda y Peeperb (2007) these companies have done a good job, at the moment, in data collection in tourism activity. They have been commissioned, among other activities, to meet the needs and satisfaction of tourists. They know why a destination is selected as such by tourists and intermediaries, what they like and do not, and what is the value that the tourism industry in the destination. They are responsible for transmitting the needs, desires and expectations of one group to another seeking the right balance.

So, Firat and Venkatesh (1993: 246) consider that in postmodernity "marketing is the conscious and planned practice of signification and representation". This thought plays an important role because it provides the basic guidelines that lead from the citymarketing mix to the citybranding, which are the two distinct approaches to citymarketing combined here.

In this sense, Helbrecht (1994: 528) discusses the relevance of citymarketing philosophy and methods, so

"Citymarketing enables a new level of quality within the local development policy in terms of comprehensiveness, creativity and flexibility. (...) In this way citymarketing enables a strategic approach to public planning in collaboration with the private sector".

According to Ashworth and Voogd (1994: 39), "there is nothing new about places being promoted by those likely to profit from their development". Because of this, what is new is the application of marketing approaches not just as an additional but as a philosophy of place management to get selling the city. And, this way, there are, more recent developments within the marketing discipline that make the distance from traditional, general marketing to place and citymarketing shorter and the transfer of marketing knowledge easier.

Borchert (1994) commented that "the majority of publications on citymarketing are at best limited to some aspects of marketing and in most cases there exists only a weak relation with modern developments in marketing theory". One concept that has emerged in recent years and has a clear and direct relevance to marketing implementation in cities is the concept of corporate branding and corporate-level marketing, which is a theoretical and practical development of the earlier concepts of corporate image and corporate identity (eg Balmer, 1998; Balmer and Greyser, 2003). One of the basic elements of this type of marketing is the determination of the major action areas that the implementation of a strategic marketing plan should incorporate. It is the description of distinct categories that should be dealt with by city marketers 
in the effort to implement integrated citymarketing. The intention is to create a mix of components applied to the cities: product, price, promotion... and place.

For this one and other reasons, recently we have pass from citymarketing... to citybranding. Because citybranding implies a significant change of perspective on the whole marketing effort. Marketing is a process that can be used to accomplish various goals set by the city, because "to discuss city marketing solely in economic terms is to oversimplify its meaning" (Paddison, 1993: 348). So, citybranding is understood as the means both for achieving competitive advantage in order to increase inward investment and tourism, and also for achieving community development, reinforcing local identity and identification of the citizens with their city and activating all social forces to avoid social exclusion and unrest.

And finally: what do we mean by citybranding? When we talk about citybranding, we are referring to the process of branding applied to cities, that is, the process of creating, developing and managing city marks as a brand city. This concept began to generalize from the Travel and Tourism Research Association's Annual Conference in 1998 (Blain, Levy and Brent Ritchie, 2005). Fernández (2009) already noted the importance of the brand for the tourist destinations, for the citybranding. But, a full definition of the target mark, the mark entirely applicable to city, based on the previous definitions of Aaker (1991) and Ritchie and Ritchie (1998), is that of Blain, Levy and Brent Ritchie (2005:337), according whit Huertas (2011), who says that:

\begin{abstract}
"La creación de un nombre, símbolo, logotipo u otro grafismo que identifica y distingue un destino; que comporta la promesa de una experiencia memorable de viaje que se asocia exclusivamente con el destino; y que sirve para consolidar y reforzar la conexión emocional entre el visitante y el destino; que reduce los costes de búsqueda del consumidor y el riesgo percibido; todo con el objetivo de crear una imagen de destino que influya positivamente en la elección del destino por parte del consumidor ${ }^{3 \prime \prime}$.
\end{abstract}

Each of the marketing mix variables are necessary, but not sufficient in themselves to carry out a proper marketing of a product, and even more so when we refer to a service and therefore intangible. We assume that tourism, the cities, as a product, must be optimal to be desired, distribution channels have well structured and priced accordingly and fundamental, that established communications with the environment, with its target, with the objectives, needs, etc. In line with Díaz-Luque (2009b), in

\footnotetext{
3 "The creation of a name, symbol, logo or other graphic that identifies and distinguishes a destination, that involves the promise of a memorable travel experience that is associated exclusively with destiny, and that serves to consolidate and strengthen the emotional connection between the visitor and destination, which reduces consumer search costs and perceived risk, all with the goal of creating a destination image that positively influence the choice of destination by the consumer".
} 
marketing science this has been termed the 'marketing mix'. The importance of the determination of the marketing mix, meaning "the combination of marketing measures needed to achieve the desired strategy" (Ashworth and Voogd, 1990), has been highlighted in citymarketing literature (Kotler et al., 1999; Van Den Berg et al., 1990) and it is acknowledged by most commentators as an essential step in the whole marketing effort. So, the called ' $4 \mathrm{P}^{\prime}$ ' variables represent a chain of marketing activities that can be developed by organizations in different ways (Kotler, 1997). Some commentators, for example, adopt for city marketing the services marketing mix (Van Den Berg et al., 1990); others adopt a wider view: Kotler et al. (1999) adopting the marketing mix as suggested by general marketing, distinguish between four distinct strategies for place improvement:

- Design (place as character)

- Infrastructure (place as fixed environment)

- Basic services (place as service provider)

- Attractions (places as entertainment and recreation).

\subsubsection{Design of metropolitan brands: Citybrand as a strategy.}

The study of city brands and branding is strongly connected to two other concepts with significant relevance to city residents and urban communities. Two subjects:

1. The first is the matter of the city's distinctive identity. Although there is wide agreement that one of the most important assets cities possess is their local character and local identity. Citybranding can assist in an attempt to reverse this tendency, since it is largely based upon the distinctive characteristics of the city. Especially useful at this point is the examination of the organisational structure of the city, which underlines subjects such as community participation.

2. The second is the notion of the 'linking value' of products, services and especially brands, a notion developed within the influence of post-modernity on marketing thought.

As Cova (1997) remarks, brands have to serve at the same time the person in their individuality and in its paper in the group'. This is the case for city brands, especially since the city has always served and still serves as the place of this group togetherness. 
So, applying corporate branding to places demands a treatment of the place brand as the whole entity comprised of the place products, in order to achieve consistency of the messages sent. Because we start with the assertion of the ultimate goal of city marketing is to increase living standards for city residents... So, city brand want to become in the principal element to get it. Within the city marketing context and with this final objective in mind, it is the development of the city's brand and the correct understanding and treatment of its components that carry the most importance for the actual and tangible results of the whole marketing strategy and planning. The selection, use and combination of branding variables is the point of contact between theory and practice, between strategy and implementation, between planners and final users; it is the point where all efforts come together, and therefore the point of more possible conflict or satisfaction (Helbrecht, 1994). These are the goals of city branding.

Based on this idea, we get the concept of corporate branding, that has not received adequate attention by commentators interested in place and city marketing, with some exceptions: Rainisto (2003), Trueman et al. (2001), for example. A fundamental notion for corporate branding is corporate identity. So, corporate identity is a holistic concept that, in words of Riel and Balmer (1997: 355):

"articulates the corporate ethos, aims and values and presents a sense of individuality that can help to differentiate the organisation within its competitive environment".

A strong identity is very important for transmitting a consistent internal and external image among stakeholders, turning into a valuable asset (Simoes and Dibb, 2001). So, Balmer (2002) suggests that the elements that constitute a corporate identity are:

- Strategy: Management vision, corporate strategy, product/services as well as corporate performance...

- Structure: Relationships between parent company and subsidiaries, relations with alliance or franchise partners.

- Communication.

- Culture: The soft and subjective elements consisting of the mix of subcultures present within the organisation.

Hatz and Schultz (2001) suggest that creating a corporate brand is complicated and they point to the interplay of three variables: vision, culture and image. These three concepts need to be aligned in order to create a strong corporate brand. In an 
attempt to define the corporate brand, Knox and Bickerton (2003: 1013) say that "a corporate brand is the visual, verbal and behavioural expression of an organization's unique business model". So, as Simoes and Dibb (2001) comment, the brand is expressed through: company's mission, core values, beliefs, communication, culture and overall design.

Meanwhile, Balmer (2001) argues that at the center of a corporate brand is an explicit covenant between an organization and its stakeholder groups. So, corporate branding draws on the traditions of product branding, in that it shares the same objective of creating differentiation and preference.

Otherwise, according to Aaker (1996), in contemporary marketing branding is central, as it integrates all the strategic elements into one success formula, because "the entity in corporate branding has a higher level of intangibility, complexity and responsibility, making it much more difficult to build a coherent brand" (Simoes and Dibb, 2001).

Brands in general and corporate brands specifically are seen as the base for long-term success of various firms and organizations.

Some other authors (Blain, Levy and Brent Ritchie, 2005) defined the brand city as the creation of graphic elements, some values, some attractive and some promises that are to be associated with a city, as the city's identity that organizers decide and communicate marketing, and positioning to be achieved. This refers to the identity of the city brand.

So every city should have a brand essential component to configure its full existence, which are the following (Huertas, 2011):

1. The elements that make up the identity of the brand, which the organizers wish to communicate marketing and that are associated with the city. Ther are:

a. The graphic element, which involves the creation of a symbol and a logo.

b. The functional conceptual element, consisting of real and tangible characteristics of the city.

c. The emotional conceptual element, consisting of abstract and symbolic values that you want to associate with the city.

2. The elements that make up the city's brand image, how it is perceived by its stakeholders, the positioning purchased. It also consists of three elements: 
a. The perception of the graphic element by audiences. It is the understanding and acceptance of the logo and the graphical components of the brand.

b. The perception by the public of the functional elements inside the city, its attractive, its valuation and disposition toward them.

c. The perception of the emotional values that identify with the city and with which they can be identified or not.

\subsection{Shopping}

\subsubsection{Shopping tourism as a playful experience}

Tourism and shopping have always been related; throughout history, travelers have used some of the time your trip souvenirs, typical local products, curios and all kinds of things as a souvenir of the trips. Another type of relationship would be the actual shopping tourism: tourism whose main motivation is to buy, to which are added stimulus similar to those of souvenirs, like getting exclusive or unique products, art products, technology, culinary and fashion do not are in the place of origin or whose price is much lower, since this provides a certain social status.

This type of tourism, 'shopping tourism' is not new, and although currently covering all types of products, although the main elements have always been all related with fashion, gastronomy and art. So, since the early twentieth century, this is getting up with the proliferation of designers... Because emerge cities that have placed part of its attraction in stores, as Metha and other expressed (2014).

It is true that, traditionally, this type of shopping tourism has been associated with the concept of fashion ... And, in this sense, the classical fashion capitals, cities considered worldwide icons, have always been, and continue to, Paris, Milan, New York and London. But increasingly emerging new cities that offer fashion... and other purchases as attractive: Dubai, Tokyo, Stockholm, Singapoore, Hong Kong, Buenos Aires, Sao Paulo... and, recently, in Spain, Madrid, Barcelona o Seville, for example.

As with most forms of tourism, there are also shopping for high and low seasons, traveling more sales time, of which the best example is New York, considered a paradise for the sales outlets and apply important discounts; it is especially attractive for Europeans, due to the devaluation of the dollar against the euro. 
But, why shopping is so important in the tour itinerary? If we go to International Council of Shopping Centers, we can say the next reasons:

1. Tourists buy unnecessarily.

2. Tourists want to find products with substantial discounts.

3. The shopping is an extension of the entertainment and amusement elements that form the center of tourist attraction.

4. For tourists whose main interest is hiking, shopping becomes a part of urban life, such as government buildings, churches etc. So, many cities, shopping centers (open or closed) or regular shops, not only have a variety of architectural styles, also has been designed to reflect the environment, culture, and economic history of their local communities. Also many malls are strategically located in the center of cities, quickly accessible from all major hotels and railway fertilizers that carry tourists. So, this is tourism too.

5. Tourists have more time, taking that break from your daily routine of work and family, and enjoy the time with no time to indulge in buying.

But, besides this all this, we can wonder why tourists spend more money than the usual buyer. The International Council of Shopping Centers prepares an annual report where it gives some information about this question:

1. Many tourists go to shop centers or areas with the intention of buying gifts, unlike a regular consumer will evaluate offers and may make comparative shopping in other centers.

2. The tourists are on holiday and therefore more in a state of impulse spending.

3. The domestic and foreign tourists want to take advantage of lower rates of sales tax, sales and cheap merchandise or not found at home.

4. Tourists have more money than the average buyer.

The motivation of shopping tourism is not only getting exclusive or unique products that are not in the place of origin or whose price is much lower, but is part of the symbolic value that these assets represent, ie, certain standard of living or social status.

\subsubsection{Commercial places as public spaces.}


Trade plays a key role in the policies to revitalize cities whose strategies especially emphasized the development of terciaria activity (Benach, 1994). So, the attempt to create an attractive, active and vibrant provide employment, services, goods and leisure and fitness takes also in malls (Holcomb and Beauregard, 1981). As Carreras, Domingo and Sauer (1990) explain, in many cases the development of new commercial forms is relatively recent and coexists with traditional forms of small establishments. Unlike the latter, however, the center business is very often much more than a place where you perform a commercial transaction. Although the commercial space is always an instrumental space, which is the ultimate purpose of selling, its role can also be analyzed as civic space as liminal space (Goss, 1992).

In this sense, a mall can often be decoupled from the act of buying and owning the role of public space, open to the world and not necessarily where people is buying. As civic space meets the mall, especially the big commercial model such the typical American mall, with all-inclusive and intended to be a world in itself, this feature may be necessary in a suburban context but in the urban center only be explained, in addition to not break up the clientele, to create a coherent world and absorbent enough to retain those who visit. So, the consideration of the mall as liminal space ie, a space that uses a controlled intermingle, intentions and symbols of different sign, something goes even further by noting the attractiveness of the shopping center as a result of the merger of the experiences of the carnival, festival and tourism in one area, becoming in a place for the enjoyment (Goss, 1992).

The consideration of commercial and liminal spaces involves not only the purchase consideration as a mean or as an excuse to engage in urban culture, but the merger of public space for private use, private space and public use. The paradigmatic example of this type of mall spaces are integrated into the new public spaces as waterfronts recovered. Thus we come to see the commercial spaces as spaces for public use, dissociated from the act of buying but characterized by the attraction.

Among these new commercial spaces, in line with Benach (2000) and, more recently, Methas and other (2014) we can distinguish several types clearly distinguished:

A. Commercial spaces that are the main attraction of leisure space, we find:

1. Commercial spaces that constitute a closed world in itself, ie, outside there is nothing to see other than other stores.

2. Central traditional commercial spaces, however, unlike what has happened in other cities, there never have become decadent. 
B. Leisure spaces comprising, as an added attraction, the commercial space:

1. Commercial spaces integrated into tourist attractions, of which they are part as an element, perhaps the best example today can be found in many cities around the world is constituted by the renovations of waterfronts, where the use commercial and recreational complement and become inseparable.

In these three cases we can say that it is possible to decouple the mall but the act of buying, however, can hardly be isolated from the attraction as spaces of consumption, which contribute not only as commercial spaces but also as spaces leisure.

\section{Methodology and corpus}

This study is the result of research that combines qualitative and quantitative methods of collecting data for further analysis. Specifically an analysis of a specific case study: the city of Seville. In carrying out the implementation of the case study used the following research techniques: case study combined interviews, surveys and direct observation.

For Pérez (2004:81) the case study is to test and analyze deep so intensely diverse phenomenon that is the life cycle of the unit. This definition fits with our intent to subject empirical behaviour of a particular case, the trade-tourism in the city of Seville.

We conducted a case study because according to authors such as Yin (1988) and Pérez (2004:80-83) the case study method is empirical research that examines a contemporary phenomenon within its real context, led to situations that the boundaries between the phenomenon and context are confusing, and use multiple sources of evidence. It applies primarily to our research the case study method, focusing on the unique case design. This methodology allows to give a logical validity in this research: approaching the study of the trade-tourism from a communicational perspective.

To conduct the case study, supplemented with observation techniques, interviews and surveys. 


\subsection{Observation}

For Gonzalez (1997) observation is one of the procedures used to collect information that is systematic and carefully consider how social life develops. It refers to the set of techniques developed for direct observation of events occurring in a natural way. This definition implies two main considerations: first, that the data are collected when the event occurs, without implying the impossibility that is recorded or collected for further analysis, and secondly, it means that the event is created, maintained or terminated solely for research. According to the cited author states, is the most important investigative technique used in sociology so that no other technique can replace direct contact with the researcher's field of study and states (Gonzalez, 1997:124):

"No other technique is able to suggest many new ideas. It is hard to imagine a serious study in which observation plays no role. Any investigation should start after a phase of observation ".

There are two types of observation: the systematic observation and participant (Gonzalez, 1997:126). And systematic observation refers to the observation and recording of behaviours and actions specified previously. It can be applied whenever the selected area occurs in public situations and allows the researcher to conduct the observation without being directly involved in the situation. However, unlike the systematic observation, participant observation the researcher is part of the events observed. In this sense, in the specific context of this study the specific technique used is that of systematic observation, as in the words of González (1997:126) "recommends the use of observational methods when formulating new hypotheses as performed exploratory and descriptive research". As stated earlier, the nature of our research design, which combines the study exploratory descriptive - explanatory reason that justifies the use of systematic observation technique in the present investigation. Systematic observation is that events observed are selected, annotated and coded (...).

Regarding the latter considerations below we review both the selection of the sample on which the technique is applied and the design of the tool through the establishment of events that had previously been selected to be observed in the data collection. 
What do we observe? The improvement about the commercial centers in the city, the public services, and the touristic campaigns to attract tourists. This all in Seville, Andalusian.

\subsection{Interview}

As scientific procedure for data collection, the interview refers to the process of interaction where information flows asymmetrically between two distinct roles, of which one question and one answer (González, 1997: 154). In our research, the interview as a complementary technique, allows access to specific and concrete information that is not contained in the secondary data sources that represent the main body of analysis. However there are different types of interviews. One or the other must be selected under the more appropriate response to the research purpose.

Corbetta (2007: 34 ) provides two types of instruments to learn to pose questions to the subject: the quantitative survey and qualitative interview. The selection of the other should be in terms of the problems and the purpose of the research being done. In this regard says González (1997: 156): "The existence of different types of interview allows more technical choice, but not arbitrary. There is a direct correspondence between the type of interview to use and the purpose of the information to be obtained in the development of the investigation".

Against another type, the qualitative interview is unique in allowing "get data by asking a respondent to know the individuality of the person interviewed and see the world through their eyes" (Corbetta, 2007: 344) implying that the interviewee is selected by the possibilities for information, in-depth, it can bring on the subject of the investigation.

In this sense, for Corbetta (2007), the qualitative interview meets the following conditions:

- Is a conversation explicitly requested by the interviewer

- Which is usually done through a scheduled

- Which is performed at a series of selected subjects

- According to a systematic plan of data collection. 
That is, the respondent is not occasional but chosen by certain characteristics: lives, experiences, etc. .. As data collection technique is a tool through which you can get the information underlying structured speeches, highlighting the views, doubts and contradictions, something difficult to capture through a closed-ended questionnaire. The information obtained in this way is much more richly nuanced and allows a more complete approach to the phenomenon studied.

We interview to 15 commerce entrepreneurs of Seville, 5 responsibles of trade policy, and 5 tourists.

\subsection{Survey}

The survey is one of the main tools for exploration of the social sciences. So we propose a quantitative questionnaire, a survey with questions semi - closed questions (yes / no and why) to see reactions and arguments simpler issues, and some openended questions, to extract some data that we can escape. They are online and offline questionnaires to obtain feedback from the situation about the commerce in Seville.

This questionnaire is done in two ways: through a percentage by application OPINA, an online software to make surveys being done via the Internet, and another physical percent through paper and questions face to face. The electronic questionnaires are self-administered, so that the questions should be simple and clear instructions should be provided (Malhotra and Birks, 2006).

Prior to the general administration, the questionnaires should be tested in small groups of respondents as to identify and eliminate problems. All aspects of a questionnaire should be tested, including the content, writing, vocabulary, sequence, shape and arrangement, and the degree of difficulty of the questions and instructions (Malhotra and Birks, 2006).

We question:

- The perception of the tourists about the city (Seville) as a shopping city

- The perception of the commerce entrepreneurs of Seville about the trade promotion policies by local governments 
How did we do? In physical questionnaires (paper) and virtual (online).

How do we select interviewees? We need, in principle, a random sample. How many people do we select? We propose a survey of 1000 individuals.

\section{Results}

Encourage sales of shops and restaurants in the capital of Andalusia is one of the objectives in the "II Plan Estratégico Sevilla 2020"4. For this reason, it is have raised (not carried out, at least at the moment) a series of initiatives promoted by the organisms such Ayuntamiento de Sevilla ${ }^{5}$ and Diputación Provincial de Sevilla ${ }^{6}$, along with the various Cámaras de comercio and tourism, as well as various local associations:

- Confederación de empresarios de Andalucía

- Asociación de comerciantes de Asunción

- Asociación Céntrico Sevilla

- Federación provincial de comerciantes de Sevilla

The proposals were:

- Pedestrianization of certain streets

- Improved public transport

- Openness and trade liberalization schedule

- Tours dining and shopping

- Campaign promoting tourist shopping in Seville

Among these proposals, some were carried out, as the pedestrianization of certain streets (Constitution Ave., Asunción street ${ }^{8}$ ), liberalization of business hours (which has

\footnotetext{
${ }^{4}$ II Strategic Plan Seville 2020

${ }^{5}$ Seville Town Hall

${ }^{6}$ A local public organization

${ }^{7}$ Chambers of commerce

8 They are two streets famous in Seville because their commerce and shops.
} 
led to much criticism, and that far from matching the Spanish model to Europe Nordic countries, for example-, makes it different, with a greater number of hours open to the public), conducting commercial and gastronomic routes and campaigns such "En Sevilla, como un rey", "En Sevilla, como un rey, siempre"10 o "Mapping Sevilla"11, among any others.

The results of the surveys revealed that local people didn't appreciate the changes performed and the tourists who were surveyed, although they were satisfied with their purchases, they did not consider the supply of stores as the item because they decided to visit the city. But, however, the increased of sales of tourists was important, as is shown by reports of Tax Free ${ }^{12}$ (although this fact just shows that purchases by tourists were higher, not that the actions had effects).

Moreover, the interviews showed that, in general, the commerce and shops entrepreneurs aren't satisfied with the actions done by the local organizations. So, although all of them asserted that some initiatives are good, the way which were made didn't so good. An example: The pedestrianization of streets was a very good initiative to attract buyers (tourist or not) but the time for the improvement works Street did that during two or three years had many economic losses... And this fact had no solution or consideration. Also, the interviews with the representative of chambers and associations showed similar opinion: although global projects and strategy were good, the implementation of actions, tactics, was wrongly executed.

The observation indicated that in the last years the commerce in Seville has been modernized, but not enough to claim that shopping is a touristic attractiveness, but not enough to claim that shopping is the cause because tourists visit the city. Even with the outlets malls that offer low prices and coming renewing its image, offerings and campaigns, such The Outlet Style Seville, recently modernized. Just SIMOF ("Salón Internacional de la Moda Flamenca"13) gets mobilize specific tourists in search of typical Spanish fashion.

\footnotetext{
${ }^{9}$ http://www.youtube.com/watch?v=Gm4CPo6udPw

${ }^{10}$ http://www.youtube.com/watch?v=wSb_QrG8MJ8\&list=UUYqeWiPhqoYlz5fo-

VPCIMg\&index $=0$ \&feature $=$ plcp

${ }^{11} \mathrm{http}: / /$ www.youtube.com/watch?v=zoXD8m20mes

12 System to promote sales and to avoid double taxation tourists. The system consists of a tax refund VAT (Value Added Tax) on purchases over 90 euros.

13 International Flamenco Fashion Show
} 


\section{Discussion and conclusions.}

Shopping tourism is a type that is increasingly evolving, although started as just an add-on trips, it has become a form of tourism potential very important to the economy. From being a simple shopping while on a trip to be the main activity around which creates all kind of services. This type of tourism are the Shopping Outlet Villages, towns created by shops, in order to establish themselves as destinations in themselves devoted to shopping and in which there are all kinds of necessary services such as accommodation, restaurants, transportation, entertainment etc.

A big number of cities in the world is improving its offers of service touristic shopping with special offers, routes and ads campaigns to attract them: Madrid has the "Madrid Sunday Shopping", or Barcelona has the "Route of the designers"... and, in this line, New York has "The sales"; Singapore, its "Technological Route" and, for example, Stockholm its "Biblioteksgatan Route", a route with Swedish design label...

However, Seville is in a full process to change its offer of shopping to adapt for the tourism. At moment, the city is improving its services, its campaigns, its image for shopping tourism, but now this is not a reality.

Perhaps in the future, the city can get a real route for shopping tourism with a big and fort image in other cities or other countries. The seeds are being planted now.

\section{Documentation}

AA.VV. (2016): Informe estadístico Familitur 2015. Ministerio de Economía.

AA.VV. (2011): "II Plan estratégico Sevilla 2011-2020". Sevilla, Ayuntamiento de Sevilla.

AA.V. (2009): "El turismo mundial crece a pesar de la crisis", en Andalucía Turismo Digital. Disponible en http://www.andaluciaturismodigital.com. [consultado el 14/1/2009].

AA.V. (2008): "El turismo en España durante el 2007" en Instituto de Estudios Turísticos.Disponible en http://www.iet.tourspain.es.[Consultado el 27/2/2017].

AA.W. (2007): Plan Integral de Calidad Turística Española 2007-2012. Ministerio de Economía.

AA.V. (2004a): "Coyuntura turística 2015-2017" en Instituto de Estudios Turísticos. Disponible en http://www.iet.tourspain.es. [Consultado el 27/2/2017]

AA.V. (2004b): "El turismo mundial creció un $12 \%$ hasta agosto, con 526 millones de llegadas" en Andalucía Turismo Digital. En http://www.andaluciaturismodigital.com. [Consultado el 14/1.2009].

AA.W. (1998): Turismo. Panorama 2020. Previsiones. Madrid, Ediciones de la Organización Mundial del Turismo (OMT). 
AGENCIAS (E.P.): AA.W. (2011): "El sector turístico elevó un 3,4\% su superávit en 2010" en Andalucía Turismo Digital. Disponible en http://www.andaluciaturismodigital.com. [Consultado el 01/03/2011].

ARCHADALE, G. (1993). "Computer Reservation System and Public Tourist Offices". Tourism Management, 14, 3-14.

Ayala, Francisco (1972): "Propaganda y democracia", en Hoy ya es ayer, Madrid, Moneda y Crédito, pp. 193-200.

BIGNÉ, Enrique (2000): Marketing de destinos turísticos: análisis y estrategias de desarrollo. Madrid, ESIC.

BROWN J. y CURCH, A. (1987): "Theme parks in Europe: riding high in the 1980's". Travel and Tourist Analyst, Feb. 1987, pp. 35-46.

BENACH, N. (1994): "La promoción de nueva actividad terciaria en la ciudad de Barcelona", Finisterra, XXIX, no. 57 pp. 43-60.

BENACH, N. (2000). "Nuevos espacios de consumo y construcción de imagen de la ciudad en Barcelona." Estudios Geográficos LXI(238): 189-205.

BUHALIS, D. (2000) "Marketing the competitive destination of the future". Tourism Management, Vol. 21, Pp. 97-116

BUHALIS, D. (2003). e-Tourism, information technology for strategic tourism management. Essex, United Kingdom: Prentice Hall.

BUHALIS, D., y LICATA, C., (2002) "The future of eTourism intermediaries". Tourism Management, Vol.23, Pp. 207-220,

Chapman Brown, Harold (1929): "Advertising and Propaganda: A Study in the Ethics of Social Control", en International Journal of Ethics, vol. 40, no 1. (Oct., 1929), pp. 39-55.

Cogswell, David (1997): "History is Not Over. Mechanisms Exist to Change the System. A Conversation with Noam Chomsky", April 18, 1997, en http://www.halpc.org/ clyndes/Chomsky.htmICARRERAS, C., DOMINGO, J.SAUER, C. (1990): Les àrees de concentració comercial de la ciutat de Barcelona, Barcelona, COCINB.

COOPER, C., FLETCHER, J., GILBERT, D., WANHILL, S. (1997): Turismo, principios y práctica. México, Diana.

DEL PINO, C. y OLIVARES, F. (2007): Brand placement: integración de marcas en la ficción audiovisual, Barcelona, Gedisa.

DÍAZ-LUQUE, P. (2009a). Metodología para la presencia de las zonas turísticas españolas en Internet. Tesis doctoral publicada por el Servicio de Publicaciones de la Universidad de Málaga.

DÍAZ-LUQUE, P. (2009b): "Official Tourism Web Sites and City Marketing". En GASCÓ-HERNÁNDEZ y TORRES CORONA: Information Communication Technologies and City Marketing: Digital Opportunities for Cities Around the World. New York, Information science.

DÍAZ LUQUE, P., GUEVARA, A. y CARO, J. L. (2004) "Promoción turística de las Comunidades Autónomas en Internet". En TURITEC 2004, V Congreso Nacional de Turismo y Tecnologías de la Información y las Comunicaciones. Universidad de Málaga. pp 35-52.

DOOLIN, B., BURGESS, L y COOPER, J. (2002) "Evaluating the use of the web of tourism marketing: a case study from New Zealand". Tourism Management Vol. 23, pp 557-561.

HERRERO, J. L (2008). 'Descubriendo la razones para introducir el comercio electrónico en las webs de destinos turísticos". En TURITEC 2008, VII Congreso Nacional de Turismo y Tecnologías de la Información y las Comunicaciones, Universidad de Málaga.

ESTEBAN, A.; MARTÍN-CONSUEGRA, D; MILLÁN, A. y MOLINA, A. (2002): Introducción al Marketing. Barcelona, Ariel Economía. 
FERNÁNDEZ CAVIA, J. (2009): "Ciutats, regions i països com a marques: llums i ombres del place branding". In Manual de Comunicació Turística. De la informació a la persuasió, de la promoció a l'emoció. Girona, Documenta Universitaria.

FERNÁNDEZ, G.; PAZ, S. (2005): "Más allá del marketing de ciudades: hacia una política pública de diseño y gestión de los signos de identificación de ciudad". Scripta Nova. Revista electrónica de Geografía y Ciencias Sociales. Universidad de Barcelona, Barcelona, de agosto de 2005 Vol. IX (No 194). [Disponible en http://www.ub.es/geocrit/sn/sn-194-94.htm] (Consultado el 21 de febrero de 2011)

FIRAT, A. F. and VENKATESH, A. (1993): "Postmodernity: The age of marketing", International Journal of Research in Marketing, Vol. 10, No. 3, pp. 227-249.

FOLCH, R. (coord. )(2003): El Territorio como sistema. Conceptos y herramientas de ordenación, Barcelona, Diputació de Barcelona.

FORDA, R. C., y PEEBERB, W.C. (2007). "The past as prologue: Predicting the future of the convention and visitor bureau industry on the basis of its history". Tourism Management, 28, Pp 1104-1114.

FUERTES EUGENIO, A. M.y MOLINA PUERTAS C.A. (2000): "Los parques temáticos como estrategia de producto" en Cuadernos de CC.EE. y EE., № 39, pp. 37-58.

GARCÍA UCEDA, Mariola (1997): Las claves de la publicidad. 2a Edición Revisada, Madrid, ESIC.

GARRIDO, Manuel (2003): "El nuevo consumidor de destinos turísticos", en REY, Juan, FERNÁNDEZ, Jorge David y PINEDA, Antonio (eds.): Consumo, publicidad y cultura, Sevilla, MAECEI Ediciones, pp. 97-110.

GARRIDO, Manuel (2005): "Comportamiento estratégico de la promoción turística española", Comunicación, n03, pp. 125-140.

GARTRELL, R. B. (1994) Destination Marketing for Convention and Visitor Bureaus, 2nd ed. Dubuque, IA: Kendall/Hunt Publishing.

GOLD, J.R. WARD, S.V., ed. Place Promotion. The Use of Publicity and Marketing to sell Towns and Regions, Chichester, John Wiley and Sons, pp. 93-114.

GÓMEZ PIÑEIRO, F. J. (1998):"Geografía y Sistemas en el análisis interdisciplinar de la problemática ambiental", en Lurralde(Investigación y Espacio), n021, Donostia-San Sebastián, Instituto GeográficoVasco.

GONZÁLEZ RÍO, M. J. (1997): Metodología de la investigación social. Técnicas de recolección de datos. Alicante, Aguaclara.

GOSS, J. (1992): "The magic of the "mall": An analysis of form, function, and meaning in the contemporary retail built environment", Annals of the Association of American Geographers, no. 82, pp. 1-47.

GRETZEL, U., FESENMAIER, D. R., FORMICA, S., y O'LEARY, J. T. (2006). "Searching for the Future: Challenges Faced by Destination Marketing Organizations". Journal of Travel Research, 45, Pp 116-126.

HARVEY, D. (1989): "From managerialism to entrepreneuralism: The tranformation in urban governance in late capitalism", Geografiska Annaler, 71B, no. 1 pp. 3-17.

HOLCOMB, H.B., BEAUREGARD, R.A. (1981): Revitalizing Cities, Washington, Ass. Am. Geographers.

HUERTAS (2011): "Las claves del citymarketing" en Lecciones del Portal, Universidad Autónoma de Barcelona. In http://portalcomunicacion.com/lecciones_det.asp?lng=esp\&id=57.

KALAKOTA, R., y WHINSTON, A. (1996). Frontiers of electronic commerce. London: Addison Wesley Longman.

KOTLER, PHILIP; HAIDER, DONALD H.; REIN, IRVING (1994): Mercadotecnia de localidades. Cómo atraer inversiones, industrias y turismo a ciudades, regiones, estados y países. México, Diana. 
LÓPEZ, J. M. (2007): "Planificación Estratégica y Marketing de Lugares". En: Imago Urbis. Quilmes, Argentina.

MARCUSSEN, C. H. (1999). Internet Distribution of European Travel and Tourism Services. Copenhagen: Hakom Holm.

MEHTA, S. AND OTHERS (2014): "Impact of Tourism on Retail Shopping in Dubai", International Journal of Trade, Economics and Finance, Vol. 5, No. 6, December 2014

MUÑOZ OÑATE, F. (1997): Marketing turístico. Madrid, Ed. Centro de Estudios Ramón Areces.

PAREJO, T. (2004): La Estrategia Territorial Europea. La percepción comunitaria del uso del Territorio, Madrid, Instituto Pascual Madoz del Territorio, Urbanismo y Medio Ambiente y Ed. Marcial Pons.

PÉREZ SERRANO, G. (2004): Investigación cualitativa. retos e interrogantes. Madrid, Editorial La Muralla.

PRECEDO, A. (2004): Nuevas realidades territoriales para el sigloXXI. Desarrollo local, Identidad Territorial, ciudad difusa, Madrid, Ed. Síntesis.

PUJADAS, R. y FONT, J. (1998): Ordenación y Planificación Territorial, Madrid, Ed. Síntesis.

POON, A. (1993). Tourism, technology and competitive strategies. Oxon, United Kingdom: Cab International.

RASTROLLO, M. A. y ALARCÓN, P. (1999). "El turista ante el comercio electrónico". Revista de Estudios Turísticos, N. 142, pp 97-116.

ROMERO, J. y FARINÓS, J. (eds. ) (2004): Ordenación del Territorio y desarrollo territorial. EI gobierno del Territorio en Europa: tradiciones, contextos, culturas y nuevas visiones, Gijón, Ed. Trea.

SCHIFFMAN, Leon G., y KANUK, Leslie L. (1991): Comportamiento del consumidor. México, Prentice Hall.

SHELDON, P. (1997). Information technology for tourism. Oxford: CAB.

TAX FREE REPORT ANNUAL (2011).

VELTZ, P. (1999): Mundialización, Ciudades y Territorios, Barcelona, Ed. Ariel.

WERTHNER, H., y KLEIN, S. (1999). Information Technology and Tourism, a Challenging Relationship. Vienna: Springer Verlag

WTO (1999). Marketing tourism destinations online: strategies for the information age. Madrid: World Tourism Organization.

YIN, R. (1988). Case Study Research: Design and Methods. Sage Publications. United Kingdom.

YUAN, Y., GRETZEL, U., y FESENMAIER, D. R. (2003). "Internet technology use by American Convention and Visitors Bureaus". Journal of Travel Research, 41, Pp 240-255. 